ward ; but when placed within five or six feet of the hen mother, they, in answer to her call, became much more lively, began to make little forward journeys, and soon followed her by sound alone, though of course blindly. Another experiment consisted in rendering chickens deaf for a time by sealing their ears with several folds of gum paper before they had escaped from the shell. These, on having their ears opened when two or three days old, and being placed within call of the mother concealed in a box or on the other side of a door, after turning round a few times ran straight to the spot whence came the first sound they had ever heard. Clearly, of these chickens it cannot be said that sounds were to them at first but meaningless sensations.

One or two observations favourable to the opinion that animals have an instinctive knowledge of their enemies may be taken for what they are worth. When twelve days old one of my little protéges running about beside me, gave the peculiar chirp where. by they announce the approach of danger. On looking up, a sparrow-hawk was seen hovering at a great height over head. Again, a young hawk was made to fly over a hen with her first brood of chickens, then about a week old. In the twinkling of an eye most of the chickens were hid among grass and bushes. And scarcely had the hawk touched the ground, about twelve yards from where the hen had been sitting, when she fell upon it, and would soon have killed it outright. A young turkey gave even more striking evidence. When ten days old it heard the voice of the hawk for the first time, and just beside it. Like an arrow from the bow it darted off in the opposite direction, and crouched in a corner, remained for ten minutes motionless and dumb with fear. Out of a vast number of experiments with chickens and bees, though the results were not uniform, yet in the great majority of instances the chickens gave evidence of instinctive fear of these sting-bearing insects.

But to return to examples of instinctive skill and knowledge, concerning which I think no doubt can remain, a very useful instinct may be observed in the early attention that chickens pay to their toilet. As soon as they can hold up their heads, when only from four to five hours old, they attempt dressing at their wings, that, too, when they have been denied the use of their eyes. Another incontestable case of instinct may be seen in the art of scraping in search of food. Without any opportunities of imitation, chickens begin to scrape when from two to six days old. Most frequently the circumstances are suggestive; at other times, however, the first attempt, which generally consisis of a sort of nervous dance, was made on a smooth table. The unacquired dexterity shown in the capture of insects is very remarkable. A duckling one day old, on being placed in the open air for the first time, almost immediately snapped at, and caught, a fly on the wing. Still more interesting is the instructive art of catching flies peculiar to the turkey. When not a day and a half old I observed a young turkey, which I had adopted while yet in the shell, pointing its beak slowly and deliberately at flies and other small insects without actually pecking at them. In doing this its head could be seen to shake like a hand that is attempted to be held steady by a visible effort. This I recorded when I did not understand its meaning. For it was no until afterwards that I observed a turkey, when it sees a fly settled on any object, steals on the unwary insect with slow and measured step, and, when sufficiently near, advances its head very slowly and steadily until within reach of its prey, which is then seized by a sudden dart. In still further confirmation of the opinion that such wonderful examples of dexterity and cunning are instinctive and not acquired, may be adduced the significant fact that the individuals of each species have little capacity to learn anything not found in the habits of their progenitors. A chicken was made, from the first and for several months, the sole companion of a young turkey. Yet it never showed the slightest tendency to adopt the admirable art of catching flies that it saw practised before its eyes every hour of the day.

The only theory in explanation of the phenomena of instinct that has an air of science about it, is the doctrine of Inherited Association. Instinct in the present generation of animals is the product of the accumulated experiences of past generations. Great difficulty, however, is felt by many in conceiving how anything so impalpable as fear at the sight of a bee should be transmitted from parent to offspring. It should be remembered, however, that the permanence of such associations in the history of an individual life depends on the corresponding impress given to the nervous organisation. We cannot, strictly speaking, experience any individual act of consciousness twice over; but as, by pulling the bell-cord to-day we can, in the language of ordinary discourse, produce the same sound we heard yesterday, so, while the established connections among the nerves and nervecentres hold, we are enabled to live our experiences over again. Now, why should not those modifications of brain-matter, that, enduring from hour to hour and from day to day, render acquisition possible, be, like a ny other physical peculiarity, transmitted from parent to offsp ring? That they are so transmitted is all but proved by the facts of instinct, while these, in their turn receive their only rational explanation in this theory of Inherited Association.

\section{ON THE TREE-FERNS OF THE COAL MEA- SURES, AND THEIR AFFINITIES WITH EXISTING FORMS *}

I INDLEY and Hutton describe two species of tree-ferns from the Coal Measures, both from the Bath Coal-field. I have been able to add eight species hitherto undescribed, chiefly throngh the assistance of Mr.J. M'Murtrie, of Radstock, These belong to three groups, which are remarkably distinguished by peculiarities in the structure of the stems. Two of the groups belong to living forms, while the third is extinct, being confined to Palæozoic formations. Caulopteris and Tubicaulis belong to the same type as the living ferns which possess stems, including under this term the humble stems (falsely called rhizomes) of many of our British species, as well as the arborescent ferns of warmer regions; and excluding the rhizomatous forms like Pteris, Polypodium, and Hymenophyllum. In all these stems we have a central medulla, surrounded by a continuous vascular cylinder penetrated regularly by meshes, from the margins of which the vascular bundle or bundles to the fronds are given off, and through which the parenchyma of the medulla is continuous with that of the stipes. In most tree-ferns the medullary axis is larger, and the bases of the stipes decay down to the circum. ference of the stem, but in Osmunda the persistent bases of the stipes permanently clothe the small vascular cylinder which encloses a slender pith. To this latter form belongs the stipe with a dumbell-shaped vascular bundle, separate specimens of which I have obtained from the Coal Measures. These have been described both on the Continent and in this country, under the name of Zygopteris, but they belong to Cotta's genus Tubicaulis; and they are very closely allied to a group of fern stems which I have already placed together under the name of Chelepteris. The stem structure of the common tree-fern is represented by the genus Caulopteris, of which I have six species of carboniferous age.

The third and extinct group is represented by Corda's gentis Stemmatopteris, only now known to be British, and by Psaronius, which is, however, not a separate generic form, but only the internal structure of the stems of which Corda's genus is the external aspect. The chief characters of Psaronius have been drawn from the structure of the aerial roots which invest the stem, from which, indeed, the generic designation was derived; while the structure of the stem itself has been overlooked. But this is really of the first importance, as will appear from the following description which I have been able to make from a finely preserved specimen of an undescribed species in the British Museum, and from the figures of Cotta and Corda. The circumference of the stem was composed of a continuous envelope of indurated tissue; within this there were perpendicular tracts of vascular tissue never penetrated by any mesh. Between these tracts the leaves were given off in perpendicular series, the large single leaf bundles coming right out from the central parenchyma, where they existed as well-formed bundles, filling up more or less completely the medullary cavity. In one form (Zippea) the leaves are opposite, and the great proportion of the circumference of the stem is made up of the persistent and common vascular tissue; in others (species of Psaronius) the permanent elements of the stem consists of three, four, six or more perpendicular tracts.

The first two groups are analogous in the arrangement of the parts of their stems to that which exists in the first year's growth of a dicotyledon. In both there is a parenchymatous medulla surrounded by a contintous vascular cylinder, which is perforated in regular manner by meshes for the passage out of the vascular elements of the appendages. The stems of the third group have a structure analogous to that which is found in the stems of monocotyledons, for in both we have the vascular

* Paper read before the British Association at Brighton in Section C, Aug. 19 , by W. Carruthers, F.R.S. 
bundles of the appendages existing in the parenchymatous axis, and passing out independently of any closed cylinder. The permanent elements of the circumference of these stems of Psaronius are, however, without any analogue in the monocotyledonous stems.

There seems, then, good reason for establishing two groups of ferns, with differences characteristic of their stems, comparable to those which distinguish the stems of monoctyledons from those of dicotyledons. But the caution $I$ have always insisted on in dealing only with vegetative organs is specially required here, for I have discovered, I believe, the fruiting fronds of one species of this group of plants. With the Bath specimens of Stemmatopteris insignis, Corda, as well as with those found on the Continent, the fronds of Pecopteris arborescens are always associated. It is the only fern found with some of the Bath specimens. It is also to be observed that the bases of the stipes correspond with the size of the leaf scars on the stems. These facts are not absolutely sufficient for the correlation of the fronds with the stem, but they are the best evidence for this that we can expect in fossil botany short of actual organic union. Now the fruit of Pecopteris arborescens is so near to that of Cyathea that I can find no characters whereby they can be separated. Our classification based on the stems must of course yield to that derived from the organs of fructification, and our group of ferns, instead of being made into a new order, as would be the case by some who publish on fossil botany, must be grouped with a tribe of recent Polypodiaceer.

It may seem that this is a forced and arbitrary grouping together of plants that in some important characters so remarkably differ; and so it is undoubtedly to those who, with rash confidence, generalise on the systematic position of plants from stem structure alone. But what can such objectors say to the practice of placing in close proximity plants that are beyond question nearly related to each other in all essential characters, though some have caudices, while others possess rhizomes; yet these two forms of stems are yet more widely separated from each other than the extinct palæozoic group is from the recent forms,

\section{SCIENTIFIC SERIALS}

THE double number (Nos. 5 and 6) of the Annalen der Chemie und Pharmacie commences with a paper by Carl Grunzweig, on "Butyric acid from different sources." He prepared the perfectly pure normal and isobutyric acids and their salts, and examined their properties very carefully; he then examined butyric acid as obtained from butter, which he finds to be normal butyric acid, and the acid from the oxidation of conine and that from the carob, or St. John's bread, are also the normal acid,-Von Schneider contributes a long paper upon pollen and wax formation; which is followed by a second contribution by Kachler on the compounds of the camphor group. He has accurately examined into the properties of campholic acid and some of its salts, and aiso into the action of bromine and phosphoric chloride on that body. The action of bromine is to oxidize the acid, forming oxycamphoric anhydride, hydrobromic acid being produced in quantity. He has also examined camphinic acid.-Weselsky follows, with an important paper on the azocompounds of resorcin, in the theoretical parts of which some most elaborate graphic formulæ are brought to' life. - Liebermann and Chojnacki have again examined rufiopin, which was first obtained by Anderson from opianic acid. The authors' researches show that it belongs to the anthracene group, as by the action of zinc powder at a high temperature this hydrocarbon can be obtained from it. It therefore belongs to the same series to which the colouring matters alizarin and purpurin belong, being the next higher body in the series to purpurin. -Dittmar and Kekulé contribute a paper on an aromatic glycollic acid. The starting point for the production of this body is toluylic acid, which is acted on by bromine, and the resulting bromo-compound again acted on by barytic hydrate. The oxymethylphenylformic acid obtained forms small plates or needles as crystallised from water. - Amato has endeavoured to obtain dicyanacetic acid by treating dichloracetic ether with potassic cyanide. He has not succeeded in obtaining the acid, but seems to have produced a body which has resulted from the decomposition of dicyanacetic ether with two molecules of water.-This number contains 18 original papers, several of which, however, are translations from foreign journals.
Annalen der Chemie und Pharmacie, No. 7.-This number commences with a lengthy article on chrysanisic acid, by $\mathrm{H}$. Salkowski. This acid was discovered by Cahours, in the year I849, and has been experimented on by many chemists. Kekule has proved that it has the constitution of a dinitrobenzoic acid, of the formula $\mathrm{C}_{6} \mathrm{H}_{2}\left(\mathrm{NO}_{2}\right)_{2}\left(\mathrm{NH}_{2}\right) \mathrm{CO}_{2} \mathrm{H}$. Dr. Salkowski has now made some experiments on this and its derivatives. Chrysanisic acid is obtained by treating anisol with nitric acid of $\mathrm{r}^{\circ} 4$ sp. gr., which converts it into nitro-anisic acid; this latter body is then treated with red fuming nitric acid, the product of which action is submitted to the action of ammonia, which yields ammonic chrysanisate. This crystallises easily, and the acid can be obtained from it in the pure state without difficulty. The author has prepared a number of the salts of this acid, which are here described in detail. By the action of hydrochloric acid and tin on chrysanisic acid, triamidobenzoic acid is produced; this acid, on heating, is decomposed into triamidobenzol and carbonic anhyduride. Triamidobenzoic acid appears to possess both acid and basic properties, as it can form salts with both strong acids and bases. Both classes of salts have been prepared and are described. Thus triamidobenzoic acid forms a compound with two molecules of hydrochloric acid, and also with one of sulphuric acid. Chrysanisic acid, by the action of strong hydrochloric acid, yields trichlorobenzoic acid; and by the action of nitrous acid, dinitroparoxybenzoic acid is obtained. From this body the monethyl and diethyl derivatives can be prepared.An interesting paper on the influence of potassium and sodium salts on fermentation, by C. Knapp, follows. He finds that both potassium and sodium salts, more especially the chlorides which he has worked with, exert a hastening influence on alcoholic fermentation, the potassium chloride being the better of the two. He also finds that a small percentage of the salt acts more vigorously than a large one.--Richard Maly contributes two papers on the colouring matter of bile, \&c. ; and Liebermann and Van Dorf follow with an exhaustive paper on the cochineal colouring matters. - The next paper is by Beilstein and Kohlberg, on isomerism in the benzol series. This is the fourteenth contribution from these authors on this wide subject, the present treating on cinnamic acid and metanitrobenzoic acid.

Bulletin de l'Académie Impériale des Sciences de St. Petersburg, t. xvii., No. I.-This number contains an important paper by Prof. Kamintzin on the employment of inorganic salts as a means for studying the development of lower organisms containing chlorophyll. He studied the action of salt solutions of specified composition and various concentration on forms of algæ, chiefly Chlorococcus infusionum and Protococcus viridis. The algæ and higher cryptogams bear a higher concentration than the phanerogams. In a 3-per-cent, solution they develop vigorously; in solutions under two per cent. zoospores were produced, these again forming zoosporangia ; but where the concentration was higher the development was by division into round motionless bodies. Prof. Kamintzin also studies the development of individual varieties, owing to internal causes, the external conditions remaining the same, thus extending to the lower plant forms the class of observations made by Darwin in the animal kingdom. The plasticity of various forms of alg $x$ under the above treatment is fully shown and illustrated.-O. Grimm describes the integumental structure of one of the Crinoidea, the Comatula mediterranea. Certain small canals observed in an internal fibrous layer he considers to be organs of respiration, the water entering by small openings on the external surface,-There are two short papers by Dr. Levschin on the development of osseous tissue and the structure of terminal blood-vessels in the bones of the newly-born. In a paper by Dr. Gruber, the dissection of a hand having two thumbs is described, and compared with three other cases of the same kind:

\section{SOCIETIES AND ACADEMIES LONDON}

Royal Microscopical Society, October 2.-Dr. Hudson read a paper "On Pedalion mira," and exhibited specimens under the society's microscopes. This curious little animal was discovered last year by Dr. Hudson near Bristol, and a figure and short description of it is given in the Monthly Microscopical Fournal for September I871. - The President read a paper " On the Development of the Skull of the Crow."-Dr. Woodward sent a series of photographs for exhibition, showing the resolution of Nobert's roth band with a Tolles lens, which was not properly corrected for chromatic errors. 